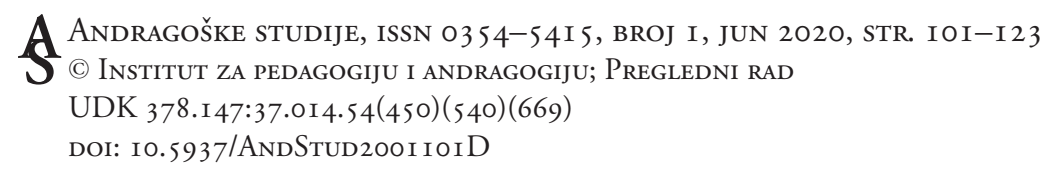

Debora Daddi ${ }^{1}$

University of Florence, Italy

Vanna Boffo ${ }^{2}$

University of Florence, Italy

Debahash Buragohain ${ }^{3}$

University of Delhi, India

Tobi Charles Iyaomolere ${ }^{4}$

University of Lagos, Nigeria

\title{
Programmes and Methods for Developing Entrepreneurial Skills in Higher Education
}

\begin{abstract}
The development of entrepreneurial competences among graduates is considered an important resource in many countries, not only because through these competences graduates can better contribute to the economic well-being of their communities by creating enterprises but also because through them, they can better direct their career development in any sector. The most successful entrepreneurship education programmes combine the development of technical and transversal skills using specific methodologies. In this paper, we evaluate in a comparative way the extent to which university-based entrepreneurship education programmes in Italy, India and Nigeria use methods that develop participants' ability to move from ideation to the implementation of something new. The literature review shows some differences between the programmes and methods developed in the three countries but also some shared strategies in adopting lines of development aimed at increasing students' entrepreneurial skills.
\end{abstract}

Key Words: Entrepreneurship education programmes, higher education, university programmes, methods, skills

\footnotetext{
${ }^{1}$ Debora Daddi, PhD student in Education and Psychology, Department of Education, Languages, Intercultures, Literature and Psychology, University of Florence, Italy (debora.daddi@unifi.it).

2 Vanna Boffo, PhD, full professor in Adult Education and LifeLong Learning, Department of Education, Languages, Intercultures, Literatures and Psychology, University of Florence, the president of Adult and Continuing Education and Pedagogical Sciences, (vanna.boffo@unifi.it).

${ }^{3}$ Debahash Buragohain, Research scholar, Department of Adult, Lifelong learning and Extension, Faculty of Social Science, University of Delhi, India (devburagohain@gmail.com).

4 Tobi Charles Iyaomolere, PhD student, Department of Adult Education, Faculty of Education, University of Lagos, Akoka, Yaba, Lagos, Nigeria (tobbyphilip@yahoo.com).
} 


\section{Introduction}

Entrepreneurial initiative is understood as individuals' ability to transform ideas into action. It is a key capacity of young people that helps and motivates them to be more creative and self-confident. As such, it ought to be present throughout their educational processes. The entrepreneurial spirit bolsters a nation's economy by fostering innovation, generating competition, creating jobs and wealth, and increasing purchasing power (Holmgren \& From, 2005).

Entrepreneurship has been in a difficult position within higher education across the globe. In higher education, entrepreneurship has long been understood to belong to business management, meaning that entrepreneurship education used to focus on business basics such as market analysis, business plans, franchising, and new enterprises management until the 1970s, when the focus shifted to entrepreneurship basics (Pitso, 2019).

In other words, entrepreneurship education should emphasise action-oriented attention: in this perspective, practical learning activities and responsibility towards professional career growth are the processes underlying the development of entrepreneurs.

This approach focuses on self-learning, strong action-oriented learning, real-life experiences of trying out things, and the motivation to hold something tangible at the end of the learning process.

There is growing evidence that the social and organisational context at universities has a substantial impact on the entrepreneurial attitudes and activities of academics and students (Bercovitz \& Feldman, 2008; Hunter et al., 2011; Kenney \& Goe, 2004; Walter et al. 2013).

The vast majority of youths go through college every year without gaining the employability and entrepreneurial skills required by the labour market. This indeed creates an imbalance between required and available resources, as well as increasing unemployment.

More and more universities have implemented measures to improve their programmes with the aim of fostering the entrepreneurial propensity of students and researchers (Eickelpasch \& Fritsch, 2005).

In light of all this, the need to train students for entrepreneurship through the formative process is evident in order to develop their capacity to create, recognise opportunities and assess the risks of the labour market (Detienne \& Chandler, 2004).

The objective of the present paper is to discover, through an analysis of the literature, the programmes and methods implemented for the development 
of entrepreneurial skills in higher education in three different countries: Italy, Nigeria, and India.

The methodological perspective that guides the work is the comparative method, which enabled us to identify three main categories of to compare the three countries: (i) university programmes in entrepreneurship education, (ii) methods and strategies, and (iii) skills development.

In addition to highlighting possible shortcomings and possible developments, we present a global picture of the progress related to educational programmes in terms of entrepreneurship development and employability. We ask what universities are doing and review the implementation of existing programmes with an eye on possible improvement in the future.

\section{Entrepreneurship programmes and methods in Italian higher education}

As part of the New Skills Agenda for Europe, the European Commission in 2016 paid particular attention to entrepreneurship, which was understood as a transversal competence necessary to help people be more creative, innovative, and proactive to transform ideas into values. 'These values can be of a financial, cultural or social nature.' (Moberg et al. 2014, as cited in Terzaroli, 2018, p. 36)

As Moberg et al. (2014, as cited in Terzaroli, 2018) affirm, developing entrepreneurial skills offers citizens the great opportunity to grow and develop on a personal, professional, and social level. Citizens can become people capable of seizing the opportunities that arise, knowing how to be proactive, knowing how to enter the job market.

These subject matters are central to the social and political debate, but they are also extremely relevant within the university context. The university has the ambitious goal of training students, workers, adults and young adults, participating in the process of building a personal identity and their own career, taking an interest in the individual and the world of which the individual is part. In this regard, developing tools to create this value therefore means empowering people, citizens and workers to innovate their environments, generate an effective contribution, and respond to increasingly emerging needs.

As already reported in the 2020 Entrepreneurship Action Plan, contained in the Small Business Act Review of 2011, the European Commission identifies three main pillars in which governments should invest to support the construction of an entrepreneurial Europe. Among these, we find in the first place 'entrepreneurial education and training'. Here, point A is particularly important: 'The usual 
curricula, starting from primary education up to secondary, professional, higher education and up to continuing education, are enriched with the key competence "entrepreneurship".' (Eurydice Italia, 2017, p. 29)

What are Italian universities doing to support entrepreneurship development?

In general, students believe the most important experience for developing entrepreneurship skills is an internship, especially abroad and in collaboration with companies and organisations from all sectors. In fact, this was stated in an article in Corriere della Sera:

Internships open a privileged channel for work in $37 \%$ of cases: those abroad are the most effective for employment purposes. The most enterprising students right from the educational path earn more when they find a job (from 1,265 to 1,352 euros, against the $1,164-1,212$ euros earned by the less enterprising). More than half of the graduates surveyed present themselves as highly adaptable to the needs of the job market, an adaptability that can be rewarding in terms of earnings. (Testai, 2013)

Internships represent the privileged channel offered by universities, so in recent years universities have accepted the need to train their students in entrepreneurship, offering them different and/or parallel paths to the degree course in order to acquire these entrepreneurial skills.

An example of this is il Progetto i Bicocca, studenti intraprendenti per affrontare il lavoro proposed in 2015, divided into several points. Specifically for developing entrepreneurship, we find the following two sub-projects iStudent, ambasciatori dell' innovazione, in which 32 students help other students to come up with the most suitable skills to face the challenges of the future: knowing how to manage time, how to work towards objectives, and how to be results-oriented to transform one's ideas into concrete projects (University of Milan-Bicocca); and Start $U_{p}$ Stage con Assolombarda, which is an internship programme organised among the growing start-up scene of the Lombardy region with the aim of allowing students to collaborate in the planning stages and thus increase their skills in the entrepreneurial sector. To this end, Lackeus (2015) identifies three possible approaches to entrepreneurship that universities may adopt:

- teaching about,

- teaching for,

- teaching through (Lackéus, 2015, p.10, as cited in Terzaroli, 2018, p. 37). 
The author explains:

Teaching 'about' entrepreneurship means a content-laden and theoretical approach aiming to give a general understanding of the phenomenon. It is the most common approach in higher education institutions. (Mwasalwiba, 2010, as cited in Terzaroli, 2018, p. 37) Teaching 'for' entrepreneurship means an occupationally oriented approach aiming at giving budding entrepreneurs the required knowledge and skills. (Terzaroli, 2018, p. 37)

Teaching 'through' means a process-based and often experiential approach (Kolb, 1984) where students go through an actual entrepreneurial learning process. (Fayolle et al., 2005, as cited in Terzaroli, 2018, p. 37)

In the last perspective ('teaching through'), it seems necessary to introduce design thinking as a method for developing entrepreneurship education in higher education.

What is design thinking?

Design thinking is conceived as a complex thought process that leads to the transformation of new realities, evolution and innovation, offering new models and tools that help improve, accelerate and visualise every creative process. Design thinking is not only a cognitive process or a mental attitude, it has become an effective method for every innovative process that connects the creative approach, typical of design, to traditional business thinking, based on rational planning and resolution of problems (problem-solving) of variable contexts.

Design thinking is based on the ability of designers to consider at the same time:

- human needs and new visions of living well,

- material availability and technical resources,

- the limits and opportunities of a project or a business (Pombo \& Tschimmel, 2005, p. 70).

The integration of these three factors requires designers to be at the same time analytical and empathic, rational and emotional, methodical and intuitive, aware of planning and the various limits but at the same time spontaneous.

Another fundamental characteristic of design thinking is the human-centred approach, which is expressed in the collaborative way in which designers work in the participatory method of co-creation. We are at the beginning of a shift from designing 'for users' to designing 'with users': designers develop innovative solutions not only by working in teams with colleagues (designers, engi- 
neers, marketing specialists, etc.), researchers and stakeholders, but increasingly also with end users and the users of their creations themselves. In this participatory approach, the user of the future product is seen as a partner throughout the entire creation process, from data collection to prototyping new ideas and designing solutions (Azzalin, 2013).

In addition to improving the image of the product and instilling a sense of belonging in the end users, co-creation increases the effectiveness of creative and innovative processes (Azzalin, 2013). This concept originated in the early 1960s and was subsequently articulated and developed in the 1990s, mainly thanks to Buchanan's publications (1998), and finally, today, it has found its own definition and modelling. The current model of design thinking, proposed by Stanford University and used most frequently around the world, is the following:

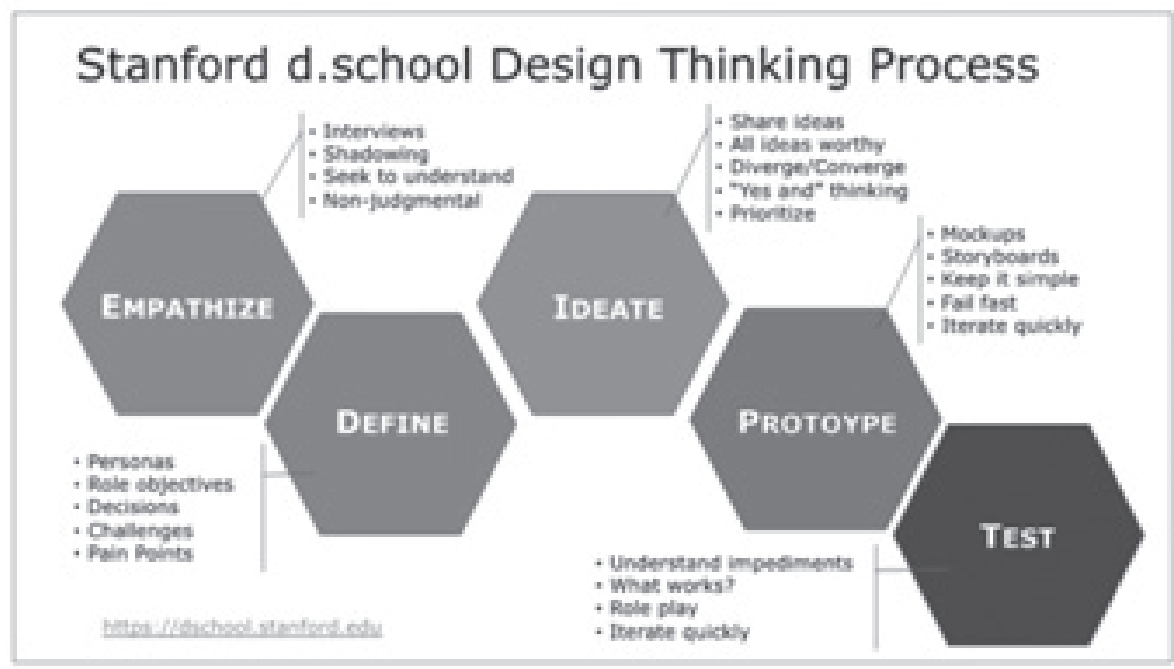

Figure 1: The design thinking process by Stanford University.

[Source: D.school Standford]

What is the link between design thinking and university?

Italian universities are increasingly supporting the existence of a link between design thinking and the development of entrepreneurship by offering courses and ad hoc activities. In this regard, the University of Florence offers a supply chain of services aimed at the development of entrepreneurship, including the so-called Palestra di Intraprendenza, a two-day workshop in which students of different degree courses (bachelor's, master's, and $\mathrm{PhD}$ ) collaborate in a creative process to produce innovative solutions in response to real problems. 
The purpose of this activity is to involve students through an experiential path in the field ('teaching through', Lackéus, 2015, p. 10), in line with the daily challenges of the labour market (University of Florence). The creation process is guided precisely by the design thinking method proposed by Stanford University.

To encourage group sharing and out-of-the-box thinking, the LEGO Serious Play method is also used, which was created precisely to facilitate communication, sharing and idea generation processes: through the use of LEGO bricks it's possible to create metaphors that portray imaginary scenarios by putting ideas into small models. (University of Florence)

For approximately two years, the University of Florence has expanded its challenge to entrepreneurship, offering this type of activity in collaboration with Italian organisations, institutions, and companies.

Students thus have the opportunity to see the real needs of the context in which they are guests and generate a creative process under the guidance of and together with experts in the sector. This refers to the 'embedded approach of teaching "through" entrepreneurship [that] can be relevant to all students and on all levels of education' (Lackéus, 2015, p.10 as cited in Terzaroli, 2018, p. 37).

Not only has the University of Florence launched paths aimed at developing entrepreneurship and resourcefulness, but another example is represented by the spin-off Epoca of the University of Modena and Reggio Emilia, a reality that was born in 2007 and figures as a 'turning point of innovation between the university and the business world' (Pagliuca, 2017).

The spin-off has seen the establishment of quarterly projects in collaboration with large Italian companies with the aim of creating multidisciplinary groups composed of students and employees of the company working side by side to generate innovative products, services and solutions (Pagliuca, 2017).

The founder of the spin-off, Professor Diego Macrì, says:

One of the most interesting cases concerned Barilla: an experience that involved over 200 people from different countries and with the most varied skills, to create a design thinking area and come up with a new approach for product development, recognised in 2016 by the SMAU award for innovation. (Pagliuca, 2017)

These examples represent some of the contributions that Italian universities are offering on entrepreneurship education in higher education. 
The paths of entrepreneurial education born in recent years bring with them very solid pedagogical foundations, recalling approaches such as Kolb's (1984) experiential learning and Lave and Wenger's (1991) situated learning, as well as embedded learning (Federighi, 2018) and service learning (Jacoby, 2015; Terzaroli, 2018).

As Dewey suggests in Experience and Nature, to describe the relationship between science, art and practice, 'knowledge is no longer achieved by direct conformity of ideas with the fixed orders of nature; knowledge is achieved by a new kind of art directed toward orders of change' (Buchanan, 1998, p. 11).

In this perspective, Italian universities are also accepting the challenge of entrepreneurship training by reviewing and transforming traditional teaching, offering practical tools capable of making their students increasingly participate in their own learning.

\section{Entrepreneurship programmes and methods in Nigerian higher education}

In 2004, the National Policy on Education (NPE) promoted adult education and non-formal education as an instrument of excellence for lifelong education. In Section 6 of the National Policy that outlines the goals of adult and non-formal education that include providing functional literacy and continuing education for adults and the youths, providing education for different categories of completers of the formal education system to improve their basic knowledge and skills, providing in-service, on-the-job, vocational and professional training for different categories of workers, and giving the nation's adult citizens the aesthetic, cultural and civic education necessary for public enlightenment.

Higher institutions are conceived as places for the transmission of knowledge and skills to learners. Whatever skills are acquired, they must be translated into practicality if individuals and society at large are to benefit from them. The world today needs solutions providers and not solutions consumers and problem creators! Surprisingly, Nigeria has not seen serious and rigid adherence to the implementation of the NPE recommendations. Many of students at the institutions of higher learning do not graduate with employable skills. Hence, the high rate of unemployment in the country has become the order of the day. Higher education in Nigeria needs to be rejuvenated to comply with the provisions of the NPE as regards skill acquisition and skill development. 
Adult education is a developmental kind of education which embraces all forms of educational experiences needed by men and women according to their varying interests and needs.

Higher education is also referred to as tertiary education. The National Policy on Education of the Federal Republic of Nigeria defines tertiary education as 'the education given after secondary education in universities, colleges of education, polytechnics, monotechnics including those institutions offering correspondence courses' (FRN, 2004: Section 8, No. 58, p. 30). Based on the above definition, higher education is provided by: (i) universities, (ii) colleges of education (iii), polytechnics, (iv) monotechnics, (v) other correspondence institutions. For the purpose of this study, we only talk about universities as an example of higher education.

Technically speaking, university education in Nigeria has crucial roles to play in ensuring that their prospective students acquire relevant skills. Sharma (2013) further noted that universities are coming under increasing pressure to ensure that their graduates are employable. According to Burnett, as cited by Sharma (2013), unemployment grows because people do not have the right skills.

The existence of the discipline in universities across Nigeria provides a better context for this discussion. Presently, there are 40 federal universities in Nigeria, and after a thorough scanning of the existence of adult education programmes, 17 of them were found (with some degree of certainty) to be running the programme. The universities selected are: 
Table 1: Universities in Nigeria with functional entrepreneurship programmes and methods in higher education

[Source: Author's own]

\begin{tabular}{|c|c|c|c|}
\hline Higher institutions & $\begin{array}{l}\text { Department } \\
\text { name }\end{array}$ & $\begin{array}{l}\text { Methods } \\
\text { of teaching }\end{array}$ & $\begin{array}{l}\text { Strategies of adult education } \\
\text { mentoring in Nigeria } \\
\text { universities }\end{array}$ \\
\hline $\begin{array}{l}\text { Adekunle Ajasin } \\
\text { University, Akungba- } \\
\text { Akoko }\end{array}$ & Adult Education & \multirow{17}{*}{$\begin{array}{l}\text { Lecture, } \\
\text { project method, } \\
\text { discussion } \\
\text { method, } \\
\text { questioning } \\
\text { Socratic method, } \\
\text { team teaching } \\
\text { method, } \\
\text { talk chalk } \\
\text { recitation method, } \\
\text { field trip } \\
\text { escort method, } \\
\text { project method, } \\
\text { microteaching } \\
\text { method. }\end{array}$} & \multirow{17}{*}{$\begin{array}{l}\text { Students Industrial Work } \\
\text { Experience Scheme } \\
\text { (SIWES), } \\
\text { Industrial Training (IT), } \\
\text { Practicum, } \\
\text { Teaching Practice }\end{array}$} \\
\hline $\begin{array}{l}\text { Bayero University, } \\
\text { Kano }\end{array}$ & Adult Education & & \\
\hline $\begin{array}{l}\text { Ekiti State University, } \\
\text { Ado-Ekiti }\end{array}$ & Adult Education & & \\
\hline $\begin{array}{l}\text { Enugu State University } \\
\text { of Science and } \\
\text { Technology, Enugu }\end{array}$ & Adult Education & & \\
\hline $\begin{array}{l}\text { Ibrahim Badamasi } \\
\text { Babangida University, } \\
\text { Lapai }\end{array}$ & Adult Education & & \\
\hline $\begin{array}{l}\text { Niger Delta University, } \\
\text { Wilberforce Island }\end{array}$ & Adult Education & & \\
\hline $\begin{array}{l}\text { Nnamdi Azikiwe } \\
\text { University, Awka }\end{array}$ & Adult Education & & \\
\hline $\begin{array}{l}\text { University of Benin, } \\
\text { Benin City }\end{array}$ & Adult Education & & \\
\hline $\begin{array}{l}\text { University of Calabar, } \\
\text { Calabar }\end{array}$ & Adult Education & & \\
\hline $\begin{array}{l}\text { University of Ibadan, } \\
\text { Ibadan }\end{array}$ & Adult Education & & \\
\hline $\begin{array}{l}\text { University of Ilorin, } \\
\text { Ilorin }\end{array}$ & Adult Education & & \\
\hline University of Jos, Jos & Adult Education & & \\
\hline University of Lagos & Adult Education & & \\
\hline $\begin{array}{l}\text { University of } \\
\text { Maiduguri } \\
\end{array}$ & Adult Education & & \\
\hline $\begin{array}{l}\text { University of Nigeria } \\
\text { Nsukka }\end{array}$ & $\begin{array}{l}\text { Adult Education/ } \\
\text { Community } \\
\text { Development }\end{array}$ & & \\
\hline $\begin{array}{l}\text { University of Port- } \\
\text { Harcourt }\end{array}$ & $\begin{array}{l}\text { Adult \& non- } \\
\text { formal education }\end{array}$ & & \\
\hline $\begin{array}{l}\text { Usmanu Danfodio } \\
\text { University, Sokoto }\end{array}$ & Adult education & & \\
\hline
\end{tabular}

For the purpose of this analysis, it is important to pay attention to the methods and strategies implemented by the Nigerian universities to support adult education and promote employability and labour market entry. 
Below are detailed descriptions of four programs adopted, in a homogeneous way, by the 17 Nigerian universities selected:

- Practicums: Also called internships or work placement programmes, these are programmes designed to provide students with practical work experience in adult education in Nigeria. The emphasis is on the importance of having students learn by doing. This is a place and avenue where students can transfer the knowledge they gained in the classroom to actual work.

- Students' Industrial Work Experience Scheme (SIWES) is a skills training programme designed to expose and prepare students at universities, polytechnics, colleges of technology, colleges of agriculture and education for industrial work situations they are likely to encounter after graduation.

- Industrial Training (IT): Industrial Training exposes students to realworld work experience to gain the knowledge through hands-on observation and job implementation. From the training, the students will develop skills that relate to work ethics, management, communication, and other issues.

- Teaching Practice: This is a temporary period of teaching/facilitating in an adult education centre under the supervision of an experienced facilitator for persons who are training to become adult education facilitators.

The choice of content of the listed schools with an adult education program was based on major thematic areas of adult education programmes, as reflected in the National Minimum Standards of the National Universities Commission (NUC). These are (i) functional literacy, (ii) ICT, (iii) women education, industrial/labour education, (iv) administration, (v) community development, (vi) cooperative management, (vii) teaching subjects, and (viii) environmental education. Suffice it to mention that some relevant courses/themes are already covered by the general studies programmes at these universities; hence they were not considered in the contents listed. Some of these courses are about entrepreneurship education, peace, and conflict resolution.

The prospects of adult education as a programme of study in Nigerian universities cannot be overemphasised. Adult education as a course of study and programme is vital in this employment-seeking generation because it has the ability and capacity to employ many people, thereby increasing the volume of employment in Nigeria. This is possible because it plays the role of accumulating the seasoned human capital of individuals who have developed themselves in one capacity or another and are ready to contribute their share to national development. 


\section{Entrepreneurship programmes and methods in Indian higher education}

Education is one of the major factors influencing the supply of entrepreneurs (Henry, Hill, \& Leitch, 2005b; Nabi, Holden, \& Walmsley, 2006). The education system, especially higher education, plays a critical role in framing the graduate entrepreneur career (Trivedi, 2016). Levenburg and Schwarz (2008) have analysed the role of culture, education, and business environment towards the graduate entrepreneurial decisions of Indian students. The Indian education system is still characterised by colonial influence and criticised for hindering entrepreneurial culture (Dana, 2000; Shivani, Mukherjee, \& Sharan, 2006). Most of the pre-liberalisation period in India witnessed the negative influence of social structure, colonial influence, religion, culture, and government regulations on entrepreneurship (Dana, 2000; Shivani, Mukherjee, \& Sharan, 2006). This appears to be a deterrent to an entrepreneurial orientation in the Indian ethos.

Entrepreneurship education has gained attraction and importance in modern higher education (Gibb \& Hannon, 2006; Blenker et al., 2014). Many researchers have highlighted the significance of evaluating entrepreneurship education and the role of entrepreneurship education in higher education (Curran \& Stanworth, 1989; Young, 2000; Storey, 2000). Assessing and evaluating the education system is a big challenge (Henry, Hill, \& Leitch, 2005b; Blenker et al., 2014).

The problem with entrepreneurship education in India is that it does not necessarily endorse entrepreneurial thinking among the students (Dana, 2001). Graduates in India are ill-prepared for taking up an entrepreneurial career, primarily because they lack an education and job-oriented mindset (DNEP, 2012). Another observation is that students who do want to pursue an entrepreneurial career are discouraged by various factors, such as lack of information on business ventures, ease of doing business, lack of start-up financing, lack of support system, lack of access to technology, and fear of failure (DNEP, 2012). In the Indian context, the entrepreneurial element in higher education is still underdeveloped, and there are no independent courses related to entrepreneurship. Such courses are usually part of the business and commerce faculty and very marginal in engineering and other faculties.

It should be noted that entrepreneurship development programmes (EDP) were initiated in 1960s with an intention to promote small businesses, and there has been a steady contribution from these programmes towards entrepreneurship (Ram, 1998). However, the EDPs have specific target groups, specialise on entrepreneurial opportunities, and are not designed for mass training through higher 
education institutions (Naik, 1998). Further, there are multifaceted challenges to teaching and developing entrepreneurs, including India's large population, discrepancies in the level of basic education, a lack of experienced teachers, a lack of proper pedagogy, and a lack of an institutional focus towards entrepreneurship (Shankar, 2012).

At the graduate level, entrepreneurial career choices or the idea of pursuing an entrepreneurial career will come to students' minds. Such entrepreneurial career perceptions can be assessed. Intention models, backed by the theory of planned behaviour (Ajzen, 1991), are designated as the best tools for predicting entrepreneurial career decisions among students (Krueger \& Carsrud, 1993; 1994). Entrepreneurial potential is the state of preparedness among students to take up an entrepreneurial career in the future or after graduation (Krueger \& Brazeal, 1994).

Recent comprehensive theories relating to the entrepreneurship option include 'career construction theory' (Savickas, 2002) and the 'theory of circumscription, compromise, and self-creation' (Gottfredson, 2002). Career construction theory divides the entire career into five broader stages: growth, exploration, establishment, management, and decline (Savickas, 2002). From an entrepreneurship point of view, the growth and exploration stages are critical. The theory further explains the exploration stages, which involve the development of attitude, intentions, beliefs, and skills needed for an entrepreneurial career. It also involves the detailed scrutiny of various career choices available and efforts towards pursuing the best career option. The theory focuses on two essential elements. The first is the state of readiness, or a pre-existing mindset towards career options. The second is career maturity, that is, the expectations regarding career options gained from the education curriculum. Thus, this theory builds a strong relationship between an individual's psychological state of readiness, education, and career options. Gottfredson's (2002) theory is more dynamic and looks at change. The theory argues that circumscription or constraints assessment is the starting point of career decision making. The individual tends to eliminate unacceptable alternatives; in this process, the subjective perception of choices plays a substantial role. The perception of alternatives is similar to 'perceived feasibility' (Krueger \& Brazeal, 1994), as proposed in the entrepreneurial potential model.

Connecting the intention models to the theory of planned behaviour offers another dimension on entrepreneurial careers. The theory of planned behaviour gives a compressive measure of an individual's intention. It has the ability to assess long-term intentions, which are unique compared to other intention models. This has made the theory of planned behaviour the most preferred model for predicting entrepreneurial intention (Krueger \& Brazeal, 1994; Autio et al., 
2001). Further, it is widely used as a tool to study the career intentions of graduate entrepreneurs among university students (Nabi, Holden, \& Walmsley, 2006).

There have been many efforts to understand the compatibility of the theory of planned behaviour and Shapero's entrepreneurial event. Krueger and Brazeal (1994), in their work Entrepreneurial Potential and Potential Entrepreneurs, combined Ajzen's theory of planned behaviour (Ajzen, 1991) and Shapero's model of the entrepreneurial event (Shapero, 1975) to develop the concept of entrepreneurial potential. Autio et al. (2001) developed an integrated model of the theory of planned behaviour and entrepreneurial event along with other demographic variables, experience, and attitude towards entrepreneurship and institutional support. Krueger, Reilly and Carsrud (2000) tested both the models with university students, finding both models to be highly validated, with slightly higher exploratory value for Shapero's model. The test also highlighted the importance of combining different theories for better understanding graduates' career decisions and students' entrepreneurial intentions.

A university supports entrepreneurial behaviour and career development through awareness creation and stimulation of ideas, from development through execution. Entrepreneurial behaviours are supported through extracurricular activities and teaching. Entrepreneurship education is also delivered by real entrepreneurs using various methods like real-world experience, games and stimulation, and case studies. This is also done through formal and informal learning. In addition, entrepreneurial universities validate outcomes of entrepreneurship learning by regular reviewing and updating the course content of entrepreneurial studies. Furthermore, expected outcomes are codified in relation to competence, skills, and knowledge in all programmes. Learning outcomes are validated at the institutional level. This is done using appropriate mechanisms such as internal and external moderators (O'Connor, 2012).

Engaging and collaborating with external stakeholders is a significant component of learning and teaching in an entrepreneurial university. However, various universities do not recognise the importance of external stakeholders such as the local government, local organisations, and communities (Audretsch, 2012). This collaboration can generate a new relationship that acts as a source of new expertise and experience to be used in entrepreneurial education. It also offers updated information to entrepreneurial universities. Finally, research results are integrated into entrepreneurial training and education. Integrating the results of research into learning and teaching is useful because it updates programme contents. However, this should be done using the current and relevant research results (O’Connor, 2012). 
Entrepreneurial universities encourage students and staff to develop skills, behaviours, and a mindset that are entrepreneurial at an individual level. Nevertheless, it is the role of the university to provide platforms upon which students and staff experience entrepreneurship, which happens once they have understood the importance of entrepreneurship and developed an entrepreneurial mindset. Such platforms may provide exposure to both students and staff, exposing them to different challenges that encourage them to develop entrepreneurial skills. It includes exposing them to real-life problems, allowing them to interact with entrepreneurs and trainings, and may also include the integration of enterprise activities in education strategies.

Universities should provide opportunities and services to act on these ideas, meaning that the universities assist students from idea creation to idea implementation. In addition, universities should link students to the external ecosystem of entrepreneurship. Institutions of higher learning should provide both industrial and academic mentorship. Mentorship is an efficient learning process used as a support tool to reinforce entrepreneurial skills acquired by students, and matching students with appropriate entrepreneurs will increase their chances of developing adaptive entrepreneurial skills required in the dynamic environment. Mentoring services should be provided to both graduates and students through alumni and other external stakeholders.

The entrepreneurial university is committed to knowledge exchange and collaboration with public sectors, society, and industry (Guerrero \& Urbano, 2010). Collaboration and partnership should be integrated into a university's institutional policies to manage relationships with all sectors. Furthermore, these policies have support mechanisms to coordinate partnerships. However, among all sectors, the university should demonstrate an active role in partnership, which means that an entrepreneurial university takes the leading role in supporting partnership with other stakeholders. In addition, the university should be involved in a range of partnerships at local, regional, and global levels.

An entrepreneurial university has a strong link with external initiatives, such as science parks and incubators, to develop opportunities for dynamic knowledge exchange. This creates added value through establishing a partnership with external environments and is done because universities are surrounded by many knowledge-intensive institutions. Therefore, a university develops mechanisms to capitalise on the knowledge acquired. This mechanism facilitates the cross-development of knowledge, collaboration space, the organisation of joint workshops, and other networking opportunities and is enhanced further when universities create opportunities for its students and staff to take part in the external environment or entrepreneurial activities. This means that universities pro- 
vide opportunities for their students and staff to take part in extensive entrepreneurial activities in the external environment. Knowledge exchange mechanisms developed by the university support collaboration with the external environment.

In addition, the entrepreneurial university provides a link to the wider community, education, and research to promote the knowledge ecosystem. Therefore, universities should have a mechanism to absorb knowledge, information, and experience created in the wider ecosystem. In teaching, this includes using strategies such as inviting guest teachers and internships. In research, contract work and collaborative partnership are used to enhance these links. However, universities should provide mechanisms to exploit entrepreneurial opportunities with industrial and commercial partners.

\section{Comparison, interpretation, and conclusion}

The goal of this article was to investigate pathways developed in Italy, Nigeria, and India to enhance entrepreneurial skills in the field of higher education. Specifically, the authors considered the use of programmes and methods offered by universities in the three countries examined. These countries were not chosen randomly but as a result of comparisons undertaken during the last edition of the Winter School 2020, held in February at the University of Würzburg.

In recent years, it has been extremely important to reflect on the implementation of entrepreneurship education, especially because of the current changes proposed by the United Nations, which affect societies all over the world. In fact, universities play a central role between education and society; in this context, entrepreneurship education represents a point of connection: entrepreneurship training creates a change of mindset, a strong attitude to innovation, and the ability to respond to emerging needs. It is possible to read this interconnection in the 17 Sustainable Development Goals, in particular objectives 4 (Quality of education), 8 (Decent work and economic growth), 9 (Industry, innovation and infrastructure), 11 (Sustainable cities and sustainable communities) (United Nations, 2020).

Our comparison confirmed the importance of entrepreneurship education in higher education in all three countries and the increasingly progressive approach to programmes aimed at enterprise.

Current Nigerian policies review the importance of higher education, especially the programmes offered, teaching strategies, and the skills of young adults. The main goal of this change of perspective is to improve basic knowledge and skills, but above all the aim is to address the great lack of employability skills in young graduates. 
For this reason, more targeted courses are activated, such as internships (called practicum in the Nigerian higher education system), which certainly seems to be the primary activity for developing this competence. Internships are considered the key vehicle for enterprise in Italy, too, especially if carried out abroad. In fact, students who complete this programme show themselves as more skilled in entering the job market, in playing an active role in society, and being more creative.

Regarding other programmes implemented in the Nigerian context, we find three more specific training programmes: the Students' Industrial Work Experience Scheme (SIWES), the Industrial Training (IT) and the Teaching Practice, all of which aim to give students the opportunity to develop skills as trainers and facilitators of adult education. The dimension of enterprise is transversal to all proposed activities.

The Indian context has seen growing reflection on the relationship between education for entrepreneurship and the development of students' professional careers, thanks to the contribution of some theories that focus on the importance of building one's career from an entrepreneurial perspective. It consists of five broader stages, including growth, exploration, establishment, management, and decline (Savickas, 2002).

Despite the great interest in these issues, Indian universities have not developed real programmes aimed at entrepreneurship.

The reason for the lack of such programmes can be found in the colonial, cultural, and religious origins, which represent a real obstacle to the development of entrepreneurship among young people. Some research (Dana, 2000; Shivani, Mukherjee, \& Sharan, 2006) points out that, due to the lack of a system that supports entrepreneurship education (economically and culturally), students find themselves unprepared to pursue a professional career aimed at entrepreneurship and innovation.

Another important element is represented by a failure to recognise the importance of involving external stakeholders such as local government, local organizations, and communities (Audretsch, 2012). Integrating business activities into the proposed educational strategies could help students understand real companies' problems by interacting with entrepreneurs in the sector. These activities, by contrast, are widely used in the Italian context, which promotes collaboration initiatives between students and local organisations.

Examples include the internship courses organised in start-up companies (Start Up Stage with Assolombarda at the University of Milan-Bicocca, Start Up 'Epoca' at the University of Modena and Reggio Emilia), and the Palestra di intraprendenza offered by the University of Florence Career Service, with the aim 
of increasing students' employability and entrepreneurial skills. The final analysis concerns the methods and tools used by universities to facilitate an atmosphere aimed at enterprise and collaboration.

In this sense, in Nigeria, the methodologies adopted by universities mainly concern teamwork, shared planning, participation in themed conferences, stimulation of discussion, acting and exploration of specific case studies.

Italy fits into this perspective by encouraging teamwork and collaboration between students and other stakeholders. With regard to methodologies, design thinking represents the opportunity for students to experience an experiential path capable of preparing them for the daily challenges of the job market, placing the emphasis on the innovative and creative process. Regarding this methodology, there is no counterpart in the other two countries examined in this article.

India, on the other hand, emphasises the importance of non-formal and informal learning, encouraging young people to search for extracurricular activities to develop entrepreneurship, such as the real-life experiences of entrepreneurs, case studies, and role play.

A summary of the comparison and interpretation is presented below:

Table 2: Comparison between entrepreneurship education programmes and methods in Italy, Nigeria, and India

[Source: Authors' own]

\begin{tabular}{|c|c|c|c|}
\hline \multicolumn{4}{|c|}{ Entrepreneurship education programmes and methods in higher education } \\
\hline Categories & Italy & Nigeria & India \\
\hline $\begin{array}{l}\text { University } \\
\text { programmes in } \\
\text { entrepreneurship } \\
\text { education }\end{array}$ & $\begin{array}{l}\text { Internship and internship abroad } \\
\text { Collaboration with stakeholders } \\
\text { (Progetto iBicocca, studenti } \\
\text { intraprendenti per affrontare il } \\
\text { lavoro, iStudent, ambasciatori } \\
\text { dell'innovazione StartUp Stage } \\
\text { con Assolombarda, Palestra di } \\
\text { Intraprendenza, Spin-off Epoca) }\end{array}$ & $\begin{array}{l}\text { Internship (Practicum) } \\
\text { Training programmes } \\
\text { with stakeholders } \\
\text { (Students' Industrial } \\
\text { Work Experience } \\
\text { Scheme, Industrial } \\
\text { Training, Teaching } \\
\text { Practice) }\end{array}$ & $\begin{array}{l}\text { Stimulate } \\
\text { reflection about } \\
\text { entrepreneurship and } \\
\text { about extracurricular } \\
\text { experiences (no } \\
\text { programme) }\end{array}$ \\
\hline $\begin{array}{l}\text { Methods and } \\
\text { strategies }\end{array}$ & $\begin{array}{l}\text { Design thinking } \\
\text { Teamwork } \\
\text { Co-work students with students } \\
\text { Field trips }\end{array}$ & $\begin{array}{l}\text { Lecture } \\
\text { Discussion } \\
\text { Field trips } \\
\text { Recitation }\end{array}$ & Study cases \\
\hline $\begin{array}{l}\text { Skills } \\
\text { development }\end{array}$ & $\begin{array}{l}\text { Employability skills } \\
\text { Entrepreneurial skills } \\
\text { Career awareness } \\
\text { Creativity and innovation } \\
\text { Proactivity }\end{array}$ & $\begin{array}{l}\text { Employability skills } \\
\text { Proactivity }\end{array}$ & $\begin{array}{l}\text { A reflection about: } \\
\text { Employability skills } \\
\text { Career awareness } \\
\text { Entrepreneurial skills }\end{array}$ \\
\hline
\end{tabular}


In conclusion, it is important to underline what the three countries have in common. Despite some differences regarding the programmes developed by Nigerian, Italian, and Indian universities, they all agree in affirming the need for an increase in the development of entrepreneurship education in order to provide students with new opportunities for personal and professional growth.

The comparative work proposed here has shown the relevance of the topic of entrepreneurial education in higher education, underlining how the universities in particular are moving towards a new way of conceiving the acquisition of skills by students. Asking what universities are doing to support entrepreneurship development is a first step to understanding the development potential of the programmes they offer.

Internships, collaboration with external stakeholders, and the creation of start-ups and projects aimed at the development of entrepreneurship certainly represent a first step towards an expansion of the concept of entrepreneurship education that, we hope, universities can adopt by offering increasingly specific programmes by supporting not only the professional careers of graduates but also their integration into society as active citizens.

\section{References}

Ajzen, I. (1991). The theory of planned behaviour. Organizational Behaviour and Human Decision Processes, 50(2),179-211.

Audretsch, D. B. (2012). From the entrepreneurial university to the university for the entrepreneurial society. Journal of Technology Transfer, 35(1), 1-9. https://doi. org/10.1007/s10961-012-9288-1

Autio, E., Keeley, R. H., Klofsten, M., Parker, G. C., \& Hay, M. (2001). Entrepreneurial intent among students in Scandinavia and in the USA. Enterprise and Innovation Management Studies, 2(2), 145-160.

Azzalin, F. (2013). Il Design Thinking e le sue applicazioni alle PMI. Il caso studio Koetania, Tesi di Laurea Magistrale in Ingegneria Gestionale. Padova: Università di Padova.

Bercovitz, J., \& Feldman, M. (2008). Academic entrepreneurs: Organizational change at the individual level. Organization Science 19(1), 69-89. https://doi.org/10.1287/ orsc. 1070.0295

Blenker, P., Trolle Elmholdt, S., Hedeboe Frederiksen, S., Korsgaard, S., \& WagNER, K. (2014). Methods in entrepreneurship education research: A review and integrative framework. Education + Training, 56(8/9), 697-715.

Buchanan, R. (1998). Wicked problems in design thinking. Design Issues, 8(2), 5-21.

Curran, J., \& Stanworth, J. (1989). Education and training for enterprise: Some problems of classification, policy, evaluation and research. International Small Business Journal, 7(2), 83-161. 
Dana, L. P. (2000). Creating entrepreneurs in India. Journal of Small Business Management, 38(1), 86.

Dana, L. P. (2001). The education and training of entrepreneurs in Asia. Education + Training, 43(8/9), 405-416.

Detienne, D., \& Chandler, G. (2004). Opportunity identification and its role in the entrepreneurial classroom: A pedagogical approach and empirical test. Academy of Management Learning and Education, 3(3), 242-257. https://doi.org/10.5465/ AMLE.2004.14242103.

Eickelpasch, A., \& Fritsch, M. (2005). Contests for cooperation: A new approach in German innovation policy. Res. Policy 34, 1269-1282. https://doi.org/10.1016/j. respol.2005.02.009

European Commission (2011). Small Business Act Review. Retrieved September 8, 2020 from https://eur-lex.europa.eu/legal-content/EN/TXT/?uri=CELEX\% 3A52011DC0078.

Eurydice Italia (2017). L'educazione all' imprenditorialità a scuola in Europa. I Quaderni di Eurydice Italia.

Federal Republic of Nigeria (2004). National policy on education. Abuja: Federal Ministry of Education.

Federighi, P. (2012), L' embedded learning o la formazione incorporate. In P. Federighi, G. Campanile, \& C. Grassi (Eds.), Il modello dell'embedded learning nella PMI (pp. 17-24). Pisa: Edizioni ETS.

Gibb, A., \& Hannon, P. (2006). Towards the entrepreneurial university. International Journal of Entrepreneurship Education, 4(1), 73-110.

GotTfredson, L. (2002). Gottfredson's theory of circumscription, compromise, and self-creation. In D. Brown (Ed.), Career choice and development ( $4^{\text {th }}$ ed., pp. 85148). San Francisco, CA: Jossey-Bass.

Guerrero, M., \& Urbano, D. (2012). The development of an entrepreneurial university. The Journal of Technology Transfer, 37(1), 43-74. https://doi.org/10.1007/ s10961-010-9171-x.

Henry, C., Hill, F., \& Leitch, C. (2005a). Entrepreneurship education and training: Can entrepreneurship be taught? Part I. Education + Training, 47(2), 98-111.

Holmgren, C., \& From, J. (2005). Taylorism of the mind: Entrepreneurship education from a perspective of educational research. European Educational Research Journal, 4(4), 382-390. https://doi.org/10.2304/eerj.2005.4.4.4.

Hunter, E. M., Perry, S. J., \& Currall, S. C., (2011). Inside multi-disciplinary science and engineering research centers: The impact of organizational climate on invention disclosures and patents. Res. Policy, 40, 1226-1239. https://doi. org/10.1016/j.respol.2011.05.024

ISFOL (2016). New Skills Agenda for Europe. Retrieved September 8, 2020, from https:// eur-lex.europa.eu/legal-content/EN/TXT/?uri=CELEX:52016DC0381

Jасову, B. (2015). Service-learning essentials: Questions, answers and lessons learned. San Francisco: Jossey-Bass. 
Lave J., \& Wenger, E. (1991). Situated learning: Legitimate peripheral participation. Cambridge University Press.

Levenburg, N. M., \& Schwarz, T. V. (2008). Entrepreneurial orientation among the youth of India: The impact of culture, education and environment. Journal of Entrepreneurship, 17(1), 15-35. https://doi.org/10.1177/097135570701700102.

Kenney, M., \& Goe, W. R. (2004). The role of social embeddedness in professorial entrepreneurship: A comparison of electrical engineering and computer science at UC Berkeley and Stanford. Res. Policy, 33, 691-707. https://doi.org/10.1016/ jrespol.2003.11.001.

Kolb, D. A. (1984). Experiential learning: Experience as the source of learning and development. Englewood Cliffs: Prentice-Hall.

Krueger, N. F., \& Carsrud, A. L. (1993). Entrepreneurial intentions: Applying the theory of planned behaviour. Entrepreneurship \& Regional Development, 5(4), 315-330.

Krueger, N. F., \& Brazeal, D. V. (1994). Entrepreneurial potential and potential entrepreneurs. Entrepreneurship Theory and Practice, 18, 91.

Krueger, N. F., Reilly, M. D., \& Carsrud, A. L. (2000). Competing models of entrepreneurial intentions. Journal of Business Venturing, 15(5), 411-432.

Minister Human Resource Development Government of India (2012). Draft New Education Policy, 2012. Retrieved from https://www.mhrd.gov.in/sites/upload_ files/mhrd/files/Draft_NEP_2019_EN_Revsed.pdf.

Nabi, G., Holden, R., \& Walmsley, A. (2006). Graduate career-making and business start-up: A literature review. Education + Training, 5, 373-385.

NAIK, S. G. (1998). Modular approach to entrepreneurship development programs in Karnataka. In J. S. Saini, \& S. K. Dhameja (Eds.), Entrepreneurship and small business (pp. 75-78). New Delhi: Rawat Publication.

O'Connor, A. (2012). A conceptual framework for entrepreneurship education policy: Meeting government and economic purposes. Journal of Business Venturing, 4(28), $546-563$.

Pagliuca, S. (2017). La nuova era del Design Thinking, La nuvola del lavoro. Corriere della sera. Retrieved September 9, 2020, from https://nuvola.corriere.it/2017/04/20/ la-nuova-era-del-design-thinking/.

Pitso, T. (2019). An Integrated model for invigorating innovation and entrepreneurship in higher education. In D. Parrish (Ed.), Innovations in higher education: Cases on transforming and advancing practice, 2020, Open access peer-reviewed edited volume. https://doi.org/10.5772/intechopen.78409. Retrieved September 8, 2020, from https:/www.intechopen.com/books/innovations-in-higher-education-cases-on-transforming-and-advancing-practice/an-integrated-model-forinvigorating-innovation-and-entrepreneurship-in-higher-education.

Ромво, F., \& Tschimmel, K. (2005). Sapiens and demens in Design Thinking. Perception as core. In Proceedings of the $\sigma^{\text {th }}$ International Conference of the European Academy of Design, EAD'06, University of the Arts Bremen. 
Salem, M. I. (2014). Higher education as a pathway to entrepreneurship. International Business \& Economics Research Journal, 13(2), 289-294.

Savickas, M. (2002). Career construction: A developmental theory of vocational behaviour. In D. Brown, \& L. Brook (Eds.), Career choice and development ( $4^{\text {th }}$ ed., pp. 49- 205). San Francisco, CA: Jossey-Bass.

Shankar, R. (2012). Entrepreneurship: Theory and practice. India: Tata McGraw-Hill.

Shapero, A. (1975). The displaced, uncomfortable entrepreneur. Psychology Today, 9(Nov.), 83-88.

Sharma, Y. (2013). A focus on skills increasingly links higher education with employment. University World News, 253(January). Retrieved May 25, 2020, from www. universityworldnews.com/article.

Shivani, S., Mukherjee, S. K., \& Sharan, R. (2006). Socio-cultural influences on Indian entrepreneurs: The need for appropriate structural interventions. Journal of Asian Economics, 17(1), 5-13.

Storey, D. (2000). Six steps to heaven: Evaluating the impact of public policies to support small business in developed economies. In D. Sexton, \& H. Landstrom (Eds.), The Blackwell handbook of entrepreneurship (pp. 93-176). Oxford: Blackwell.

Terzaroli, C. (2018). Developing entrepreneurship through Design Thinking: A new frontier for adult education. Epale Journal on Adult Learning and Continuing Education, 3, 35-46.

Testai, L. (2013). L'intraprendenza che premia i giovani. Corriere della sera. Retrieved September 8, 2020, from https://corrierefiorentino.corriere.it/firenze/ notizie/universita/2013/25-febbraio-2013/intraprendenza-che-premia-giovani-2114192056052.shtml.

TRIVedi, R. (2016). Does university play significant role in shaping entrepreneurial intention? A cross-country comparative analysis. Journal of Small Business and Enterprise Development, 23(3), 790-811.

United Nations (2020). Transforming our world: The 2030 Agenda for Sustainable Development. Retrieved September 8, 2020, from https://sdgs.un.org/2030agenda.

Università degli Studi di Firenze (2019). Sviluppo dell'intraprendenza. Career Service per studenti e laureati. Retrieved September 8, 2020, from https://www.unifi.it/ p10548.html.

Università degli Studi di Milano-Bicocca (2015). Progetto iBicocca, student intraprendenti per affrontare il lavoro, Sezione archivio comunicati stampa. Retrieved September 8, 2020, from https://www.unimib.it/node/9653.

Young, J. E. (2000). Entrepreneurship education and learning for university students and practicing entrepreneurs. In Sexton, D. L., Smilor, R. D. (Eds.), Entrepreneurship (pp. 215-238). Chicago, IL: Upstart Publishing.

Walter, S. G., Parboteeah, K. P., \& Walter, A. (2013). University departments and self-employment intentions of business students: A cross-level analysis. Entrepreneurship Theory and Practice, 37(2), 175-200. https://doi.org/10.1111/j.15406520.2011.00460.x. 
Debora Daddi ${ }^{5}$

Univerzitet u Firenci, Italija

Vanna Boffo ${ }^{6}$

Univerzitet u Firenci, Italija

Debahash Buragohain ${ }^{7}$

Univerzitet u Delhiju, Indija

Tobi Charles Iyaomolere ${ }^{8}$

Univerzitet u Lagosu, Nigerija

\section{Programi i metode za razvoj preduzetničkih veština u domenu visokog obrazovanja}

Apstrakt: Razvoj preduzetničkih kompetencija među diplomcima smatra se važnim resursom u velikom broju zemalja, ne samo zato što kroz ove kompetencije diplomci mogu da pruže značajniji doprinos dobrobiti privrede svojih zajednica stvaranjem preduzeća već i zato što kroz njih mogu efikasnije upravljati razvojem svoje karijere u bilo kom sektoru.

Najuspešniji programi edukacije o preduzetništvu nude kombinaciju razvoja tehničkih i transverzalnih veština koristeći specifične metodologije. Ovaj rad nastoji da na komparativan način proceni u kojem opsegu univerzitetski programi preduzetničkog obrazovanja u Italiji, Indiji i Nigeriji koriste metode koje razvijaju sposobnosti učesnika da ostvare pomak iz sfere ideja na konkretnu implementaciju novog.

Interpretacija literature ukazuje na razlike između programa i metoda razvijenih u tri zemlje, ali takođe i na deljenje pri usvajanju pravaca razvoja usmerenih na poboljšanje preduzetničkih veština kod studenata.

Ključne reči: programi preduzetničkog obrazovanja, univerzitetsko obrazovanje, univerzitetski programi, metode, veštine

\footnotetext{
${ }^{5}$ Debora Daddi, student doktorskih studija Obrazovanja i psihologije, Katedra za obrazovanje, jezike, interkulturalne studije, književnosti i psihologiju, Univerzitet u Firenci, Italija (debora.daddi@unifi.it).

${ }^{6}$ Dr Vanna Boffo, redovna profesorka Obrazovanja odraslih i celoživotnog učenja, Katedra za obrazovanje, jezike, interkulturalne studije, književnosti i psihologiju, Univerzitet u Firenci, šef Katedre za obrazovanje odraslih, kontinuirano obrazovanje i pedagoške nauke (vanna.boffo@unifi.it).

${ }^{7}$ Debahash Buragohain, istraživač-saradnik, Katedra za obrazovanje odraslih, celoživotno učenje i ekstenziju obrazovanja, Fakultet društvenih nauka, Univerzitet u Delhiju, Indija (devburagohain@gmail.com).

8 Tobi Charles Iyaomolere, student doktorskih studija, Katedra za obrazovanje odraslih, Fakultet obrazovanja, Univerzitet u Lagosu, Akoka, Jaba, Lagos, Nigerija (tobbyphilip@yahoo.com).
} 